\title{
Accumulation of dry substances in hydrolysate during the processing of barley malt sprouts with a celluloid enzyme complex
}

\author{
O. N. Vetrova ${ }^{1}, O . Y$. Eremina $^{1}, N . V$. Seregina $^{1}$, and $N . V$. Shuldeshova $^{1}$ \\ ${ }^{1}$ Orel State University, Orel city, Komsomolskaya street, 95, 302026, Russian Federation
}

\begin{abstract}
The article presents the results of a study of the enzymatic hydrolysis of barley malt sprouts by cellulolytic enzymes. The influence of the process parameters (temperature, substrate concentration, concentration of the enzyme preparation, duration of the process) on the output of dry substances in the hydrolysate is shown. The results of the experiments were presented by a mathematical model of the process and graphically-in the form of surface projections reflecting the mutual influence of each possible pair of factors on the dry matter content in the hydrolysate. It is found that all the studied factors have an effect on the accumulation of dry substances in the hydrolysate. As a result of optimization the parameters of the enzymatic hydrolysis process, the following parameter values were obtained: temperature $-50{ }^{\circ} \mathrm{C}$, duration of enzymatic hydrolysis- 89 min, substrate concentration - 0.37 (hydromodule 1:10), concentration of the enzyme preparation $-0.05 \%$.
\end{abstract}

\section{Introduction}

Currently, priority is given to scientific research on the development of effective technologies for the complex processing of plant raw materials. Rational use of secondary raw materials allows you to expand the range of food products, create low-waste production and increase its efficiency.

As an available raw material resource for the production of protein-carbohydrate products, the byproducts of malting barley are of interest - malt sprouts, which are formed in large quantities at malt production enterprises and are not sufficiently used for food purposes and are mainly used for animal feed.

Malt sprouts are a valuable source of dietary fiber (up to $18.5 \%$ ) and protein (up to $22 \%$ ) with a full set of essential amino acids. They contain: potassium (1364.09 $\pm 16.94 \mathrm{mg} \%)$, calcium $(339.04 \pm 7.65 \mathrm{mg} \%)$, magnesium(193.92 $\pm 2.78 \quad \mathrm{mg} \%$ ), phosphorus $(606.21 \pm 10.14 \mathrm{mg} \%)$, iron( $11.23 \pm 0.26 \mathrm{mg} \%)$, manganese $(1.652 \pm 0.024 \mathrm{mg} \%)$, copper $(0.179 \pm 0.005 \mathrm{mg} \%)$ and molybdenum $(0.106 \pm 0.020 \mathrm{mg} \%)$.Vitamins in malt sprouts are represented by thiamine $(0.52 \pm 0.15 \mathrm{mg} \%)$, riboflavin $(0.34 \pm 0.06 \quad \mathrm{mg} \%), \quad$ pyridoxine $(0.61 \pm 0.12$ $\mathrm{mg} \%)$, nicotinic $\operatorname{acid}(5.55 \pm 0.16 \quad \mathrm{mg} \%)$ and tocopherols(3.62 $\pm 0.90 \mathrm{mg} \%)$ [1].

The carbohydrate fraction of malt sprouts is characterized by the presence of fiber, hemicellulose, pectin substances, pentosans, and starch [2].

The limiting factor for the use of secondary products of malt production is the presence of a large amount of fiber, which reduces the bioavailability and digestibility of food substances. Traditional technologies of complex processing of plant raw materials use treatment with acid or alkaline solutions to increase the bioavailability of components in the production of protein-carbohydrate products. A number of works on the bioconversion of plant raw materials shows the use of a complex of cellulolytic and xylolytic enzymes. It is proved that the addition of xylanases significantly improves the work of cellulases and increases the hydrolysis of cellulose due to the solubilization of xylans in cellulose materials $[3,4,5$, $6,7,8]$.

A promising direction, in our opinion, is biotechnological methods of processing raw materials with the help of enzyme preparations of cellulolytic action, which lead to the softening of the seed shells and the preservation of all the useful properties of the raw material.

\section{The purpose and object of the study}

The aim of this work is to study the effect of conditions for the fermentolysis of malt sprouts on the accumulation of dry substances in the hydrolyzate and optimization of the obtained parameters.

The object of research is malt barley sprouts. Malt sprouts are formed during germination of barley grains for malt, are separated on sprout-cutting machines and dried to a mass fraction of moisture of no more than $15 \% .10$ batches of malt sprouts obtained in the process of germination of barley grain of the "Annabel" variety for malt were studied. 


\section{Materials and methods}

To study the process of enzymatic hydrolysis of malt sprouts, the method of rotatable experiment planning was used. Optimization of the hydrolysis conditions involved determining the influence of the following factors: temperature $\left(\mathrm{X}_{1}\right)$, duration of enzymatic hydrolysis $\left(\mathrm{X}_{2}\right)$, concentration of malt sprouts (hereinafterthe concentration of the substrate $\left(\mathrm{X}_{3}\right)$, concentration of the enzyme preparation $\left(\mathrm{X}_{4}\right)$. The dry matter content in the hydrolysate $(\mathrm{Y})$ was taken as the optimization parameters.

The conditions of the experiment are presented in Table 1.

Table 1. Limits of variation of experimental factors.

\begin{tabular}{|c|c|c|c|c|}
\hline \multirow{2}{*}{$\begin{array}{c}\text { Conditions } \\
\text { planning }\end{array}$} & \multicolumn{4}{|c|}{ Limits for measuring factors } \\
\cline { 2 - 5 } & $\mathrm{X}_{1}$ & $\mathrm{X}_{2}$ & $\mathrm{X}_{3}$ & $\mathrm{X}_{4}$ \\
\hline Main level & 50 & 90 & 0.21 & 0.045 \\
\hline $\begin{array}{c}\text { Variation } \\
\text { interval }\end{array}$ & 10 & 30 & 0.10 & 0.015 \\
\hline $\begin{array}{c}\text { Upper level } \\
(+1)\end{array}$ & 60 & 120 & 0.31 & 0.060 \\
\hline $\begin{array}{c}\text { Lower level } \\
(-1)\end{array}$ & 40 & 60 & 0.11 & 0.030 \\
\hline $\begin{array}{c}\text { Upper star } \\
\text { point (+2) }\end{array}$ & 70 & 150 & 0.41 & 0.075 \\
\hline $\begin{array}{c}\text { Lower star } \\
\text { point (-2) }\end{array}$ & 30 & 30 & 0.01 & 0.015 \\
\hline
\end{tabular}

The plan and output parameters of the experiment are presented in Table 2.

Table 2. Plan and output values of the experiment.

\begin{tabular}{|c|c|c|c|c|c|}
\hline № & $\mathrm{X}_{1}$ & $\mathrm{X}_{2}$ & $\mathrm{X}_{3}$ & $\mathrm{X}_{4}$ & $\begin{array}{c}\text { Dry } \\
\text { matter, \% }\end{array}$ \\
\hline 1 & 40.0 & 60.00 & 0.11 & 0.030 & 4.8 \\
\hline 2 & 40.0 & 60.00 & 0.11 & 0.060 & 4.5 \\
\hline 3 & 40.0 & 60.00 & 0.21 & 0.030 & 4.0 \\
\hline 4 & 40.0 & 60.00 & 0.21 & 0.060 & 4.1 \\
\hline 5 & 40.0 & 120.00 & 0.11 & 0.030 & 5.0 \\
\hline 6 & 40.0 & 120.00 & 0.11 & 0.060 & 4.8 \\
\hline 7 & 40.0 & 120.00 & 0.21 & 0.030 & 4.3 \\
\hline 8 & 40.0 & 120.00 & 0.21 & 0.060 & 4.4 \\
\hline 9 & 60.0 & 60.00 & 0.11 & 0.030 & 4.0 \\
\hline 10 & 60.0 & 60.00 & 0.11 & 0.060 & 4.2 \\
\hline 11 & 60.0 & 60.00 & 0.21 & 0.030 & 4.0 \\
\hline 12 & 60.0 & 60.00 & 0.21 & 0.060 & 3.8 \\
\hline 13 & 60.0 & 120.00 & 0.11 & 0.030 & 5.1 \\
\hline 14 & 60.0 & 120.00 & 0.11 & 0.060 & 5.3 \\
\hline 15 & 60.0 & 120.00 & 0.21 & 0.030 & 5.0 \\
\hline 16 & 60.0 & 120.00 & 0.21 & 0.060 & 4.8 \\
\hline 17 & 30.0 & 90.00 & 0.31 & 0.045 & 4.8 \\
\hline 18 & 70.0 & 90.00 & 0.31 & 0.045 & 4.9 \\
\hline 19 & 50.0 & 30.00 & 0.31 & 0.045 & 4.6 \\
\hline 20 & 50.0 & 150.00 & 0.31 & 0.045 & 4.7 \\
\hline 21 & 50.0 & 90.00 & 0.01 & 0.045 & 4.9 \\
\hline 22 & 50.0 & 90.00 & 0.41 & 0.045 & 4.5 \\
\hline 23 & 50.0 & 90.00 & 0.31 & 0.015 & 4.7 \\
\hline 24 & 50.0 & 90.00 & 0.31 & 0.075 & 4.6 \\
\hline 25 & 50.0 & 90.00 & 0.21 & 0.045 & 4.8 \\
\hline 26 & 50.0 & 90.00 & 0.21 & 0.045 & 4.9 \\
\hline $\mathrm{D}$ & & & \\
\hline
\end{tabular}

During the research, crushed malted barley sprouts were filled with a citrate buffer with $\mathrm{pH}$ 5. The concentration of the substrate and the $\mathrm{pH}$ were regulated by diluting with a citrate buffer. The temperature conditions of hydrolysis were maintained using a thermostat. Celluclast BG with a cellulolytic activity of 3500 NXU/G and Panzea BG with a xylolytic activity of $235 \mathrm{NXU} / \mathrm{g}$ were used as enzyme preparations.

The experimental data were processed using the Statistica 12.0 program. The optimal parameters of enzymatic hydrolysis were determined using the "Solution Search" tool of the Microsoft Excel software.

\section{Discussion of the results}

Studies of Russian and foreign scientists show that under the influence of enzyme preparations, the polysaccharides that make up the matrix of cell walls are modified, which causes a breaking of the native intermolecular bonds between the main structural components of the polysaccharide complex, their fragmentation and, ultimately, release $[2,3,4,6,7,8,10,11]$. The use of a complex of enzyme preparations for hydrolysis provides an increase in the degree of bioconversion of cellulose while simultaneously decomposing non-starch polysaccharides.

The graphical interpretation of the influence of the studied factors on the dry matter content in the hydrolysate is presented in the form of surface projections in Figures 1-5.

As shown in Figure 1, the maximum yield of dry substances is achieved in the temperature range from $40^{\circ}$ $\mathrm{C}$ to $60^{\circ} \mathrm{C}$ with a duration of 60 to 150 minutes. With an increase in temperature of more than $65^{\circ} \mathrm{C}$, there is a decrease in the accumulation of dry substances, which is associated with the inactivation of the enzyme preparation

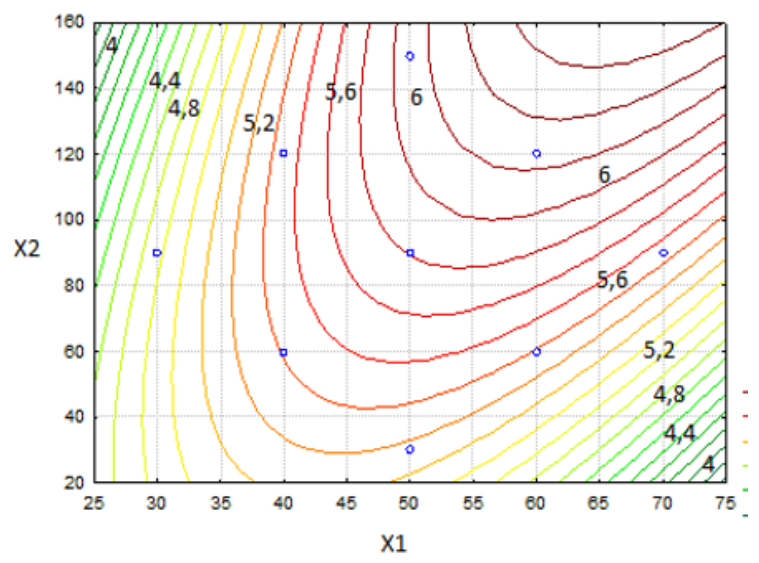

Fig. 1. Influence of temperature $\left(\mathrm{X}_{1}\right)$ and duration of enzymatic hydrolysis $\left(\mathrm{X}_{2}\right)$ on the content of dry substances substances in the hydrolysate.

It was found that the maximum accumulation of dry substances falls within the temperature range of $45-60^{\circ}$ $\mathrm{C}$, while the concentration of the substrate in the studied range (from 0.11 to 0.31 ) does not affect the content of the studied factors (Figure 2). 


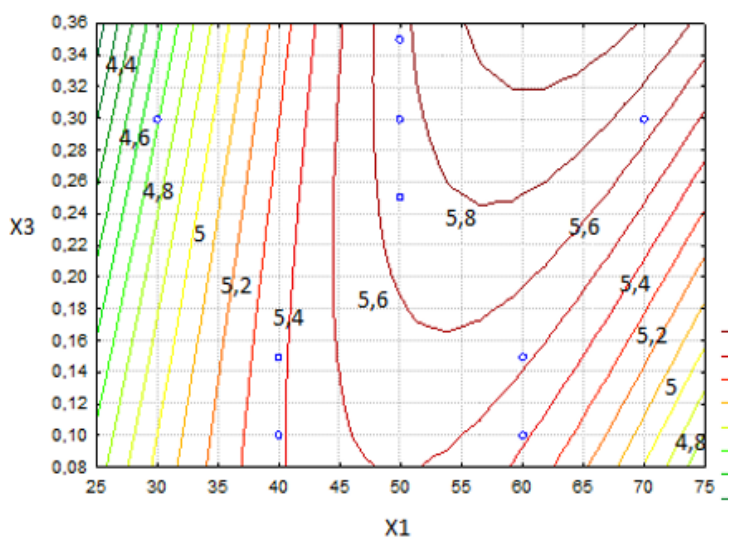

Fig. 2. Effect of temperature $\left(X_{1}\right)$ and substrate concentration $\left(\mathrm{X}_{3}\right)$ on the dry matter content in the hydrolysate.

It is determined that the highest content of dry substances in the hydrolysate is observed in the temperature range from $40^{\circ} \mathrm{C}$ to $60^{\circ} \mathrm{C}$ at all values of the concentration of the complex of enzyme preparations. It should be noted that even at the minimum concentration of the complex of enzyme preparations $(0.015 \%)$ in the specified temperature range, a sufficiently high transition of dry substances from the substrate to the hydrolysate is observed (Figure 3).

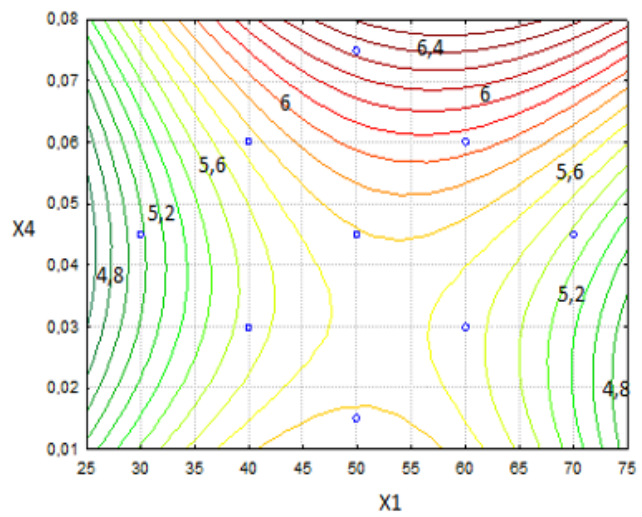

Fig. 3. Effect of the temperature $\left(X_{1}\right)$ and the concentration of the enzyme preparation $\left(\mathrm{X}_{4}\right)$ on the dry matter content in the hydrolysate.

According to the data presented in Figure 4, the greatest accumulation of dry substances is observed after 90 minutes at a substrate concentration of 0.08 to 0.31 . A sufficiently high accumulation of dry substances in the hydrolysate can be obtained with a short hydrolysis (up to 60 minutes) and a substrate concentration of more than 0.29 . However, this time of enzymatic hydrolysis will not be sufficient for the effect of the complex of enzyme preparations, which, in turn, will not ensure the release of selective ingredients from the substrate.

As shown in Figure 5, there is a sufficiently high content of dry substances in the hydrolysate at a concentration of the enzyme complex above $0.04 \%$, while it should be noted that the concentration of the substrate in the studied range does not affect the yield of dry substances in the hydrolysate.

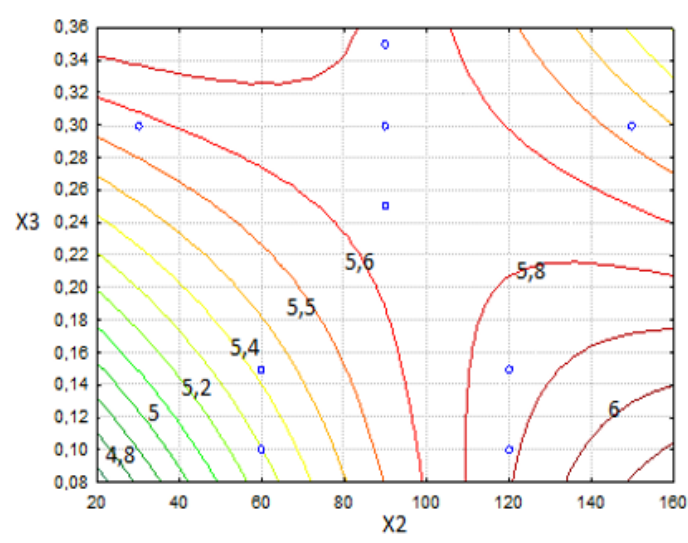

Fig. 4. Effect of the duration of enzymatic hydrolysis $\left(X_{2}\right)$ and substrate concentration $\left(\mathrm{X}_{3}\right)$ on the dry matter content in the hydrolysate.

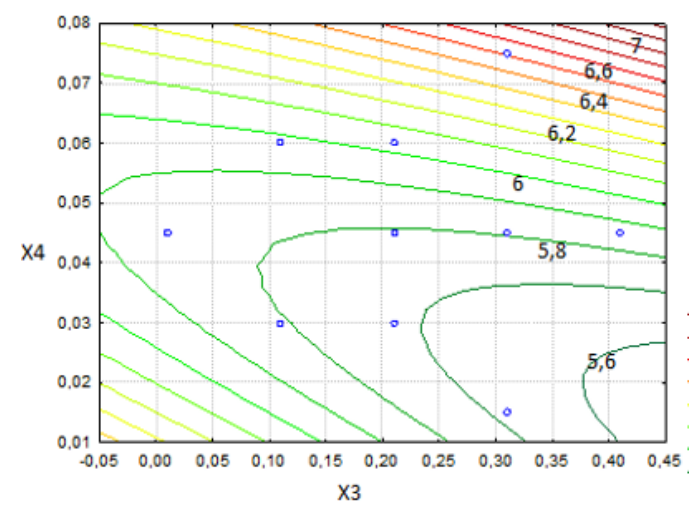

Fig. 5. Effect of the substrate concentration $\left(X_{3}\right)$ and the concentration of the enzyme complex $\left(\mathrm{X}_{4}\right)$ on the dry matter content in the hydrolysate.

\section{Conclusion}

Thus, as a result of optimizing the parameters of the process of enzymatic hydrolysis of malt sprouts with the enzyme preparations PanzeaBG and CelluclastBG using the "Solution Search" tool of the MicrosoftExcel software, a second-order mathematical model was obtained that characterizes the effect of temperature (X1), duration of hydrolysis (X2), substrate concentration (X3) and the concentration of the enzyme preparation complex (X4) on the dry matter content:

$$
Y_{C B}=5,8-0,32 X_{1}^{2}+0,31 X_{2}+0,1 X_{4}^{2}-0,45 X_{2} X_{3}
$$

The solution of this equation showed that the maximum value of the mass fraction of dry substances in the hydrolysate is $5.8 \%$ at a temperature of $50^{\circ} \mathrm{C}$, duration of 118 minutes, the substrate concentration is $0.09 \%$, the concentration of the complex of enzyme preparations is $0.08 \%$. 


\section{References}

1. Y. N. Zubtsov, O. Y. Eremina, N. V. Seregina Micronutrient value of byproducts of malting barley Questions of nutrition 86 115-120 (2017)

2. O. Y. Eremina, N. A. Berezina, O. N. Vetrova, N. V. Seregina, A.A. Gutsyna Optimization of enzymatic hydrolysis of malt barley sprouts Earth and environmental science 640 (2020)

3. L. A. Zabodalova, L. M. Kuznetsova, M. L. Domoroshchenkova, T. F. Demyanenko Application of enzymatic hydrolysis in the technology of protein concentrates Scientific Journal of the National Research University ITMO. Series: Processes and devices of food production. 2(14) 21-24 (2012)

4. A. A. Klyosov, S. Y. Grigorash Enzymatic hydrolysis of cellulose Bioorganic chemistry $\mathbf{1 0}$ 1538 - 1552 (1981)

5. E. Kuznetsova, S. Motyleva, M. Mertvischeva, V. Zomitev and J. Brindza Composition and microstructure alteration of triticale grain surface after processing by enzymes of cellulase complex Potravinarstvo Slovak Journal of Food Sciences 10 (1) 23-29 (2016)

6. E. Kuznetsova, L. Cherepnina, S. Motyleva and J. Brindza Redistribution of mineral elements in wheat grain when applying the complex enzyme preparations based on phytase Potravinarstvo Slovak Journal of Food Sciences 10 (1) 47-53 (2016)

7. E. S. Shishova, N. V. Khabibulina, A. A. Krasnoshtanova Obtaining a high-protein product from textured pea flour by extraction method coupled with enzymatic hydrolysis Butlerov communications 5 37-44 (2017)

8. E. M. Serba, L. V. Rimareva, E. I. Kurbatov, G. S. Volkova, V. A. Polyakov, V. P. Varlamov Study of the process of enzymatic hydrolysis of yeast biomass for creating food ingredients with a given fractional composition of protein substances Questions of nutrition 2 76-83 (2017)

9. T. I. Sizova Modeling of food additives on the basis of malt and malt sprouts method simplexlattice planning Technology and commodity science of innovative food products 26 44-51 (2014)

10. M.J. Selig, W.S. Adney, M.E Himmel, et al. The impact of cell wall acetylation on corn stover hydrolysis by cellulolytic and xylanolytic enzymes. Cellulose 16, 711-722 (2009)

11. J Zhang, M. Siika-aho, M. Tenkanen, L. Viikari The role of acetyl xylan esterase in the solubilisation of xylan and en-zymatic hydrolysis of wheat straw and giant reed Biotechnology for Biofuels 460 (2011) 